\title{
Using the Job-Demands-Resources model to predict turnover in the information technology workforce - General effects and gender differences
}

\author{
Peter Hoonakker ${ }^{1}$, Pascale Carayon ${ }^{1}$ and Christian Korunka ${ }^{2 *}$ \\ ${ }^{1}$ Department of Industrial and Systems Engineering, University of Wisconsin-Madison, USA \\ ${ }^{2}$ Faculty of Psychology, University of Vienna, Austria
}

\begin{abstract}
High employee turnover has always been a major issue for Information Technology (IT). In particular, turnover of women is very high. In this study, we used the Job Demand/Resources (JD-R) model to examine the relationship between job demands and job resources, stress/burnout and job satisfaction/commitment, and turnover intention and tested the model for gender differences. Data were collected in five IT companies. A sample of 624 respondents (return rate: 56\%; 54\% males; mean age: 39.7 years) was available for statistical analyses. Results of our study show that relationships between job demands and turnover intention are mediated by emotional exhaustion (burnout) and relationships between job resources and turnover intention are mediated by job satisfaction. We found noticeable gender differences in these relationships, which can explain differences in turnover intention between male and female employees. The results of our study have consequences for organizational retention strategies to keep men and women in the IT work force.
\end{abstract}

Keywords: job characteristics, organizational characteristics, job demand-resources model, employee turnover, human sex differences

\section{Uporaba modela delovnih zahtev in virov pri napovedovanju fluktuacije med zaposlenimi na IT področju - splošni učinki in razlike po spolu}

\author{
Peter Hoonakker ${ }^{1}$, Pascale Carayon ${ }^{1}$ in Christian Korunka ${ }^{2}$ \\ ${ }^{1}$ Oddelek za industrijski in sistemski inženiring, Universza v Wisconsin-Madisonu, ZDA \\ ${ }^{2}$ Fakulteta za psihologijo, Univerza na Dunaju, Avstrija
}

Povzetek: Visoka fluktuacija zaposlenih predstavlja velik problem na področju informacijskih tehnologij. Fluktuacija na tem področju je posebno visoka pri ženskah. V pričujoči raziskavi, ki temelji na teoretičnem ozadju modela delovnih zahtev in virov, smo proučevali povezave delovnih zahtev in resursov s stresom/izgorelostjo, z delovnim zadovoljstvom/pripadnostjo in z željo po menjavi zaposlitve. Podatki si bili pridobljeni v petih IT podjetjih in temeljijo na vzorcu 624 udeležencev (stopnja odzivnosti: $56 \%$; 54 \% moških; povprečna starost: 39,7 let). Rezultati so pokazali, da povezavo med delovnimi zahtevami in željo po menjavi zaposlitve mediira emocionalna izčrpanost (dimenzija izgorelosti). Odnos med delovni viri in željo po menjavi zaposlitve pa mediira delovno zadovoljstvo. Ugotovili smo tudi opazne razlike po spolu v omenjenih povezavah, $\mathrm{s}$ pomočjo katerih lahko razložimo razlike med moškimi in ženskimi zaposlenimi v želji po menjavi zaposlitve. Rezultati imajo praktične implikacije za strategije ohranjanja moških in ženskih zaposlenih na IT področju.

Ključne besede: značilnosti dela, značilnosti organizacije, job demand-resources model, fluktuacija zaposlenih, razlike med spoloma

\footnotetext{
"Naslov/Address: Christian Korunka, Faculty of Psychology, University of Vienna, Universitaetsstrasse 7, A-1010 Vienna, Austria, Tel: +43 14277 47342, e-mail: christian.korunka@univie.ac.at
} 
High employee turnover has been a major problem for the Information Technology (IT) sector since the very early days of computing and continues to be a problem (Dubie, 2009; Hoon \& Jing, 2011; Moore, 2000; Niedermann \& Sumner, 2003). IT personnel frequently change employers, and have shown this tendency ever since statistics have been kept. Studies on turnover in the IT work force conducted in the late 60's and early 70's (e.g., Stone, 1972; Willoughby, 1977) showed that annual turnover ranged between 15 percent and 20 percent in this period (Willoughby, 1977). In the late 1970s, turnover ran as high as 28 percent annually (McLaughlin, 1979) and up to 20 percent in the early 1980s. By the 1990s, the turnover rate reached 25 percent to 33 percent per year (Jiang \& Klein, 2002), and even Fortune 500 firms have similarly high turnover rates among their IT personnel (Hayes, 1998). As compared to the average all-industry voluntary turnover rates of about 10\% (2009: 8\%, 2010: 13\%, 2011: 9\%; source: SHRM Human Capital Benchmarking database), turnover in the IT sector is considerable higher. Although women have comprised nearly $48 \%$ of the total American work force throughout the last 10 years, the percentage of women in the IT workforce fell from $41 \%$ to $25 \%$ between 1996 and 2008 (Trauth, Quesenberry, \& Huang, 2006; National Center for Woman \& Information Technology, 2009). Female scientists and engineers in industry are more likely to leave their technical occupations and the workforce altogether than women in other fields. Attrition data on female scientists and engineers show that their exit rates are not only double those of men ( $25 \%$ versus $12 \%)$, but they are also much higher than those of women in other employment sectors (CAWMSET, 2000). For instance, results of a study by Lyness \& Judiesch (2001) showed a $16.5 \%$ turnover rate for female managers and $17 \%$ for male managers in financial service organizations. Results of a more recent study by Becker-Blease, Elkinawy, and Stater (2010) on turnover among nearly 18,000 executives using data from Standard \& Poor's 1500 firms, showed that $7.2 \%$ of women and 3.8 percent of men left their job in the year of the study.

Turnover of highly skilled employees can be very expensive and disruptive for firms (Reichheld, 1996; Thatcher, Stepina, \& Boyle, 2003). Losing highly skilled staff members leads companies to incur substantial costs associated with recruiting and re-skilling, and hidden costs associated with difficulties completing projects and disruptions in team-based work environments (Niedermann \& Sumner, 2003; Thatcher et al., 2003). Determining the causes of turnover within the IT workforce and controlling it through human resource practices and work system design is imperative for organizations (Igbaria \& Siegel, 1992).

This study hast the following objectives: (1) To determine the causes of turnover in IT. The Job DemandsResources (JD-R) model (e.g., Bakker, 2007), a currently widely used stress model was used as theoretical background and adapted the model for predicting turnover in the IT work force. The model explains the relationships between job demands and job stress on the one hand, and job resources and job satisfaction/commitment on the other hand, and turnover intention. (2) To test the model for gender differences. Possible direct and moderator effects of gender on the relationships in the adapted JD$\mathrm{R}$ model are examined. Especially moderator effects of gender with regard to turnover in the IT workforce were suggested (e.g., Baroudi \& Igbaria, 1995), but not empirically tested so far.

\section{Development of the research model}

One of the basic assumptions of the JD-R model is that - independent of a particular work context - work environments can be characterized by two dimensions: job demands and job resources.

Job demands are physical, psychological, social and organizational characteristics of a job, requiring physical and psychological effort and energy from an employee, which in turn are related to physiological and psychological costs (e.g., Bakker, 2007). Although job demands are not necessarily negative, they may turn into job stressors, when meeting those demands requires high effort (Bakker, Demerouti, \& Schaufeli, 2003). Stress and burnout (i.e. emotional exhaustion) can result in lower quality and performance, and in increased absenteeism and turnover.

Job resources are physical, psychological, social and organizational characteristics of a job, which are instrumental in achieving work goals, reducing job demands, and the associated costs with them, and stimulate learning. Job resources are not only functional in achieving work goals; they also stimulate personal growth and development (Bakker, 2007).

A second assumption of the JD-R model is that job demands and resources are related to well-being and attitudinal outcomes. The JD-R model postulates that the two sets of working conditions (i.e., demands and resources) may each evoke a different process. High job demands are likely to result in strain reactions (e.g., stress, burnout), which in turn may lead to an increase in absenteeism and turnover. The pathway from job demands to absenteeism and turnover via emotional exhaustion is also known as the energetic pathway. On the other hand, resources (e.g., decision latitude, social support) are likely to foster goal accomplishment, which in turn can lead to positive job attitudes (job satisfaction and organizational commitment) and reduced withdrawal behavior (reduced absenteeism and turnover). This pathway is also known as the motivational pathway (e.g., Bakker, 2007).

A third assumption of the JD-R model is that the relations between job demands and resources and outcomes are mediated by strain reactions (i.e., burnout, emotional exhaustion) on the one hand, and motivational processes (i.e., job satisfaction and commitment) on the other (Bakker, Demerouti, \& Verbeke, 2004; Lewig, Xanthopoulou, Bakker, Dollard, \& Metzer, 2007). Thus, strain reactions and motivational processes are postulated 
to be mediators between job demands/resources and turnover. Recent studies have further enhanced the JD-R model by adding work-to-family conflict as a job demand that depletes an employee's resources (Mauno, Kinnunen, \& Ruokolainen, 2006).

The JD-R model has been confirmed for a wide range of jobs and working conditions (see, for instance, a special issue 2011 of the SA Journal of Industrial Psychology), but never tested to predict turnover intention in the IT work force, which is the main goal of our study. To achieve this goal, the specific demands and resources relevant for turnover in the IT work force have to be defined.

There are two bodies of literature that have examined job demands and job resources related to turnover intention and turnover. The first body of literature is the job and organizational design and job stress literature, which focuses on job and organizational characteristics that may cause people to leave their jobs. The second body is the human resource management (HRM) literature. The HRM literature focuses on practices that help an organization to meet its strategic goals by attracting and maintaining employees and managing them effectively. Both bodies of literature are relevant for the JD-R model, because the job design/job stress literature focusses on job demands, and the HRM literature focusses on job resources.

The job and organizational design literature has shown that job demands such as workload (Janssen, De Jonge, \& Bakker, 1999; Houkes, Janssen, De Jonge, \& Bakker, 2003), role stressors such as role ambiguity (Baroudi \& Igbaria, 1995; Igbaria \& Greenhaus, 1992; Igbaria \& Guimaraes, 1999), lack of challenge (Mathieu \& Zajac, 1990) including task repetitiveness (Cotton \& Tuttle, 1986; Mobley, 1977) and routinization (Griffeth, Hom, \& Gaertner, 2000), are positively related to turnover.

Work-family conflict can be considered as a job demand, which has also been negatively linked to several organizational outcomes such as job satisfaction, organizational commitment, job stress and turnover (Frone, Russell, \& Copper, 1992; Hoonakker, Carayon, \& Schoepke, 2005; Ahuja, 2002). In many IT-related jobs, employees are expected to work late, be on-call to solve technical problems and travel extensively; all of these factors can result in conflicts between working and family life. Work-family conflict has been defined as "a form of inter-role conflict that occurs when the demands of work and family are mutually incompatible" (Greenhaus \& Beutell, 1985). The two components of work-family-conflict, family matters that conflict with working life (FWC) and work factors that conflict with family life (WFC), can add to the psychological demands placed upon workers and therefore affect their well-being, stress and depression (Googins, 1991), physical ailments (Frone, Yardley, \& Markel, 1997), life satisfaction (Higgins \& Duxbury, 1992) and turnover (Armstrong, Riemenschneider, Allen, $\&$ Reid, 2007). This is particularly true for women (GrantVallone \& Donaldson, 2001).

On the other hand, the job and organizational design literature shows that job resources such as decision latitude (Beehr, Glaser, Canali, \&Wallwey, 2001; Kim \& Stoner, 2008), social support (both supervisory support and support from colleagues (Jawahar \& Hemmasi, 2006; Lee, 2004; Mobley, Griffeth, Hand \& Meglino, 1979; Rhoades \& Eisenberger, 2002)), and Person-Organizationfit (Verquer, Beehr, \& Wagner, 2003) may instigate a motivational process leading to job-related learning, work engagement and organizational commitment (Blau \& Boal, 1987) and a propensity to stay in the organization.

Stress/burnout has also been found to be significantly correlated to turnover intention (Moore, 2000). Emotional exhaustion (a core dimension of stress/burnout) is linked to reduced job satisfaction (e.g., Burke \& Greenglass, 1995; Maslach \& Jackson, 1984), reduced organizational commitment (e.g., Leiter, 1991; Sethi, Barrier, \& King, 1999), and high turnover and turnover intention (e.g., Firth \& Britton, 1989; Jackson, Turner, \& Brief, 1986; Moore, 2000; Pines, Aronson, \& Kafry, 1981)). Technology professionals are particular vulnerable to work exhaustion (Kalimo \& Toppinen, 1995; Moore \& Burke, 2002). Work overload, role ambiguity, role conflict, lack of autonomy and lack of rewards can be considered as risk factors for burnout among IT professionals (Moore, 2000; Nelson, 1996; Sonnentag, Brodbeck, Heinbokel, \& Stolte, 2001).

Human Resource Management (HRM) literature focuses on practices (i.e. resources), which help an organization to meet its strategic goals by attracting, maintaining and effectively managing employees. One of the basic assumptions of HRM is that employee involvement and commitment can have a positive effect on organizational performance, such as higher productivity and quality of products and services, and reduced absenteeism and turnover (Lawler, 1986, 1992, 1996). The HRM literature stresses the importance of job resources such as training (availability and satisfaction with training opportunities at the company), developmental (e.g., management development programs, coaching from peers and supervisors, mentorship) and career advancement opportunities (promotional opportunities), as well as a fair reward system.

Review studies have shown that the use of practices such as extensive recruitment, selection and training procedures, formal information sharing, and systems that recognize and reward employee merit such as performance appraisal, promotion and incentive compensation are linked to organizational outcomes, including reduced turnover(McEvoy, \& Cascio, 1985), increased productivity (Guzzo, Jette, \& Katzell, 1985), and improved financial performance (Borman, 1991; Gerhart \& Milkovich, 1992). These practices are also known as "high performance work practices" or "high involvement work processes" (U.S. Department of Labor, 1993). Several studies have shown that high involvement work practices such as work design, incentive practices, flexibility, training opportunities promotion criteria, information sharing and direction setting and high involvement work processes such as power, information, rewards and knowledge are related to turnover (Huselid, 1995; Vanderberg, Richardson, \& Eastman, 1999). Agarwal and Ferrat (2002) 
examined the relationship between HRM systems and retention in a study of 350 IT professionals in ten different organizations. Results of this study showed that employee perceptions of the fairness of HRM systems are related to turnover intention.

Reviews on employee turnover in both bodies of literature conclude that - in concordance with the JD-R model - stress/burnout on one hand and job satisfaction/ commitment on the other hand are good predictors of turnover and turnover intention (Cotton \& Tuttle, 1986; Griffeth, Hom, \& Gaertner, 2000). Low job satisfaction was found to be a significant predictor of turnover intention and turnover also in the turnover intention model of Mobley, Horner, and Hollingsworth (1978), which was at least partly confirmed in follow-up studies (e.g., Bannister \& Griffeth, 1986; Hom, Caranikas-Walker, Prussia, \& Griffeth, 1992). For example, the meta-analysis of Griffeth et al. (2000) confirmed the important role of job satisfaction for turnover intention and turnover.

Organizational commitment also plays an important role in the turnover process (Baroudi, 1985; Blau \& Boal, 1987; Sjoberg \& Sverke, 2000). However, study results are inconsistent. In some studies it has been reported that organizational commitment is more strongly related to turnover intention than job satisfaction (Baroudi, 1985). On the other hand, Igbaria and Greenhaus (1992) showed that job satisfaction has a stronger direct effect on turnover intention than organizational commitment.

\section{Demographic characteristics}

Research has also shown that personal characteristics are associated with turnover intention. Personal variables have direct effects on work-related attitudes (Arnold \& Feldman, 1982; Bluedorn, 1982; Compton, 1987; Igbaria \& Greenhaus, 1992; Cotton \& Tuttle, 1986; Mobley et al., 1979). Age and organizational tenure are positively related to job satisfaction and organizational commitment (Arnold \& Feldman, 1982; Cotton \& Tuttle, 1986; Igbaria \& Greenhaus, 1992) and negatively related to turnover (Cotton \& Tuttle, 1986). Education has been found to be negatively related to job satisfaction (Igbaria \& Greenhaus, 1992), and organizational commitment (e.g., Mottaz, 1988) and positively related to turnover (Cotton \& Tuttle, 1986). Salary has been found to be negatively related to turnover in the meta-analytic study by Cotton and Tuttle (1986). Prior research suggests that demographic variables have direct effects on turnover intention over and above their indirect effects on turnover intention through satisfaction and involvement (Igbaria \& Greenhaus, 1992; Parasuraman, 1982). Therefore, we control for personal variables in our model.

Conceptual and empirical models of turnover provide strong support for the proposition that a behavioral intention to turnover constitutes the most immediate determinant of actual turnover behavior (Baroudi \& Igbaria, 1995; Bluedorn, 1982; Cotton \& Tuttle, 1986; Fishbein \& Ajzen, 1975; Igbaria \& Greenhaus, 1992; Mobley, 1977; Parasuraman, 1982; Thatcher et al., 2003).
Thus, we included turnover intention as an outcome variable in our study based on the JD-R model.

\section{Gender}

As mentioned earlier, gender plays a specific role in the turnover process. Baroudi and Igbaria (1995) examined the role gender plays in career success within IT occupations. They found that, even when demographic variables (i.e. education, knowledge and skills) were controlled for, women in IT hold lower level positions than men, receive lower salaries and have fewer opportunities to interact with peers. There were no significant differences between men and women in job satisfaction and organizational commitment, but there was a significant difference in terms of intention to stay. Contrary to predictions, women were more likely to estimate longer continuing employment. Baroudi and Igbaria (1995) concluded that there is a need to look for gender bias in hiring, salary, promotion and personnel practices and to examine additional factors, such as family constraints, in order to explain the gender differences in turnover (Baroudi \& Igbaria, 1995; Truman \& Baroudi, 1994). Results of the study by Thatcher et al. (2003) also showed gender differences (higher rates of turnover intention in women), and they conclude that future studies should examine gender's implications for IT workers' attitudes and behavior. However, relatively little research has examined the range of job demands and job resources that can affect women in IT. The research conducted by Igbaria and Greenhouse (1992) provides a useful foundation, but does not provide a systematic test of gender differences in the relationships between job demands, job resources, stress, job satisfaction, organizational commitment and turnover intention.

Conceptually, there are two possibilities for higher turnover intention rates in women. Either there is a direct effect of gender on job demands, job resources, stress, job satisfaction, commitment and turnover intention or gender moderates the relationships between these factors. In the first case, women are more often employed in lower status jobs, experience lower quality of working life and therefore have a higher propensity to leave their jobs. In the second case, men and women experience the same job demands and job resources, but women have different attitudinal and behavioral reactions to the similar organizational experiences and practices. Although suggested by Baroudi and Igbaria (1995), the moderating effect of gender has not been tested in previous research in the IT work force.

\section{Hypotheses}

The review of the research literature has highlighted the importance of the following job demands and job resources with regard to turnover intention: job demands, role ambiguity, work-family conflict, decision latitude, work-related challenges, supervisory support, personorganization fit, training, developmental and career advancement opportunities, and fairness of rewards. 
Personal characteristics: Age, education, tenure, salary

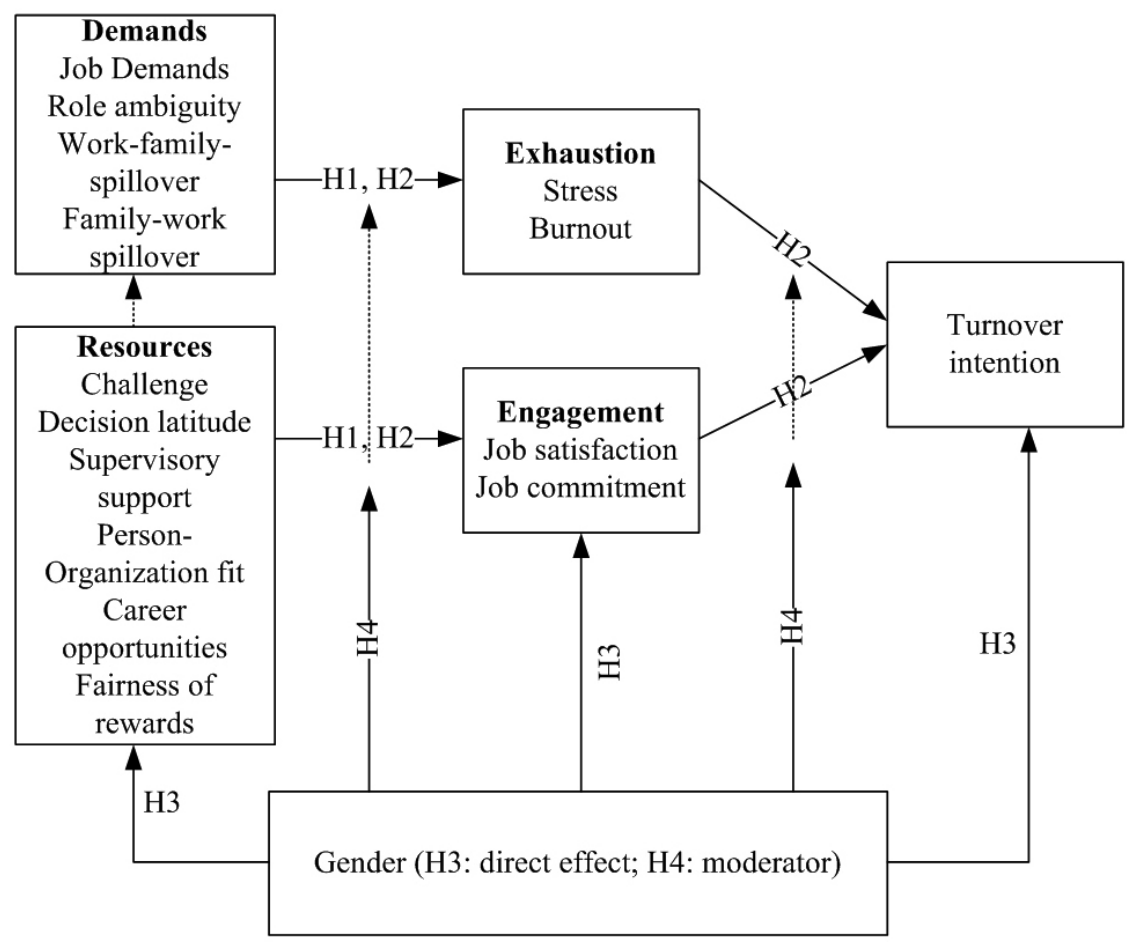

Figure 1. Conceptual model and hypotheses.

Figure 1 shows the adapted JD-R model aiming to explain turnover in the IT work force.

The first two hypotheses are based on the core assumptions of the JD-R model; the next two hypotheses are formulated to test direct and/or moderating effects of gender (figure 1).

Hypothesis 1 (H1): Job demands are positively related to job stress/burnout and turnover intention. Job resources are positively related to job satisfaction and commitment and negatively related to turnover intention.

Hypothesis 2 (H2): The job demands - turnover intention pathway is mediated by stress/burnout. The job resources - turnover intention pathway is mediated by job satisfaction/commitment.

Hypothesis 3 (H3): Gender has a direct effect on job demands and job resources, stress, job satisfaction, commitment and turnover intention. As female employees are more likely to be exposed to 'negative' job demands and/or can benefit less from job resources, they will report more stress and lower job satisfaction and commitment and higher intention to turnover (Figure 1).

Hypothesis 4 (H4): Gender moderates the relationships between job demands and job resources and stress, job satisfaction and commitment, as well as the relationship between these factors of quality of working life and turnover intention (Figure 1).

\section{Method}

\section{Participants}

A total of five Information Technology companies participated in the study. Company \#1 is the IT department of a large medical group in the Western United States. It is a large department and employs about 900 employees (response rate: 55\%). Company \#2 is an IT system integration service company in the Midwest. It is a mediumsized company and employs 190 employees (response rate: 66\%). Company \#3 is a company in the South West, providing technical, management, and administrative support services. It is a small company and employs less than 50 employees (response rate: $36 \%$ ). Company \#4 is located in the Eastern US and is focused on using different technologies and finding new and innovative ways of using that technology in order to increase business productivity. It is a small company and employs less than 50 employees (response rate: $31 \%$ ). Company \#5 provides a full range of reliable, cost effective IT services, infrastructure support, and state-of-the-art security solutions in the Eastern US. It is a small company and employs less than 50 employees (response rate: 18\%). Overall, we collected data from 624 respondents (response rate: $56 \%$ ).

Fifty-four percent of the respondents are male. Twentysix respondents chose not to reveal their gender and were excluded from the analysis. Respondents vary in age from 20 to 68 years ( $M=39.7$ years). The majority of the sample 
Table 1. Job categories in the sample in numbers (and percentages) by gender

\begin{tabular}{lccc}
\hline Job Position & Male & Female & Total \\
\hline Application software developer & $13(4.0 \%)$ & $2(0.7 \%)$ & $15(2.5 \%)$ \\
Business analyst/consultant & $12(3.7 \%)$ & $17(6.2 \%)$ & $29(4.9 \%)$ \\
Database administrator/manager/security & $10(3.1 \%)$ & $6(2.2 \%)$ & $16(2.7 \%)$ \\
Database analyst / Database architect & $2(0.6 \%)$ & $5(1.8 \%)$ & $7(1.2 \%)$ \\
Data Center Operator & $8(2.5 \%)$ & $6(2.2 \%)$ & $14(2.4 \%)$ \\
Documentation/ Technical writer & $2(0.6 \%)$ & $3(1.1 \%)$ & $5(0.8 \%)$ \\
Network administrator/manager & $14(4.3 \%)$ & $10(3.7 \%)$ & $24(4.0 \%)$ \\
Network engineer/technician/PC technician & $41(12.7 \%)$ & $5(1.8 \%)$ & $46(7.7 \%)$ \\
Project/Program/Applications/Operations manager & $61(18.9 \%)$ & $81(29.8 \%)$ & $142(23.9 \%)$ \\
Quality assurance/Testing engineer & $0(0.0 \%)$ & $2(0.7 \%)$ & $2(0.3 \%)$ \\
Server Engineer & $8(2.5 \%)$ & $1(0.4 \%)$ & $9(1.5 \%)$ \\
Software engineer/Software life cycle management & $36(11.2 \%)$ & $22(8.1 \%)$ & $58(9.8 \%)$ \\
Systems administrator/Systems security & $9(2.8 \%)$ & $0(0.0 \%)$ & $9(1.5 \%)$ \\
Systems analyst/Systems architect/Application engineer & $35(10.9 \%)$ & $48(17.6 \%)$ & $83(14.0 \%)$ \\
Systems programmer/Network software developer & $12(3.7 \%)$ & $6(2.2 \%)$ & $18(3.0 \%)$ \\
Technical support/Field technician & $24(7.5 \%)$ & $3(1.1 \%)$ & $27(4.5 \%)$ \\
Telecommunications & $5(1.6 \%)$ & $16(5.9 \%)$ & $21(3.5 \%)$ \\
Training & $0(0.0 \%)$ & $5(1.8 \%)$ & $5(0.8 \%)$ \\
Webmaster/Web site developer & $2(0.6 \%)$ & $2(0.7 \%)$ & $4(0.7 \%)$ \\
Other & $28(8.7 \%)$ & $31(11.4 \%)$ & $59(10.1 \%)$ \\
\hline Total & $322(100 \%)$ & $272(100 \%)$ & $594(100 \%)$ \\
\hline
\end{tabular}

is married (61\%), while $9 \%$ are living with a partner, $9 \%$ are single, and $8 \%$ are separated, divorced or widowed. Fifty-six percent of the respondents have children, and the vast majority of these $(83 \%)$ have children living at home. Forty-three percent of the respondents have children younger than 7 years. There are no gender differences in marital status, number of children, number of children that still live at home, or number of children younger than seven years (table 2).

Table 1 shows the distribution of men and women in the IT job categories. Results show that jobs are not equally distributed among men and women $\left(\chi^{2}=91.6\right.$, $\mathrm{p}<0.001)$. Men hold technical positions more often: nearly $90 \%$ of the technicians (technical support/field technician) and more than two-thirds of the developers (application software developers and system programmer/ network software developer) are male. Women hold analyst positions more often. Nearly two-thirds of the analysts (application analyst; business analyst/consultant; database analyst/database architect and systems analyst/ system architect/applications engineer) are female. A greater proportion of women in our sample hold positions in telecommunications and training, and more women hold managerial jobs than men (see table 1).

\section{Instrument}

The dimensions and variables identified in the literature review were incorporated in the first version of a questionnaire, which was tested in 13 interviews with key IT personnel. Based on the interviews, changes were made to the questionnaire, to address the specific problems of the
IT work force (see Carayon, Schoepke, Hoonakker, Haims, $\&$ Brunette, 2006). The final version of the questionnaire consists of five sections: (1) demographic characteristics: age, education and organizational tenure; (2) job and organizational characteristics; (3) HRM practices; (4) quality of working life; and (5) turnover intention. To measure job and organizational characteristics, HRM practices and quality of working life we used existing scales that were found to be valid and reliable in previous research. All scales we used in the questionnaire were converted to scores from 0 (lowest) to 100 (highest). Detailed information about the psychometric properties of the scales used in the study is provided in table 3 .

\section{Procedure}

We used a web-based survey to collect the questionnaire data. For a detailed description of the web-based survey system, see Barrios (2003). The participating companies in our study sent out e-mails to notify their employees of the survey. Two days later we sent the employees an e-mail describing the study, asking for their participation and providing them with a link to our web based survey. An informed consent procedure was an integrated part of the web based survey management system.

\section{Analysis}

A visual check confirmed that all variables used in the statistical analyses were normally distributed (a correlation matrix of all variables is available from the authors on request). 
Table 2. Demographic characteristics, job demands/resources, stress/burnout, attitudinal outcomes, and turnover intention by gender

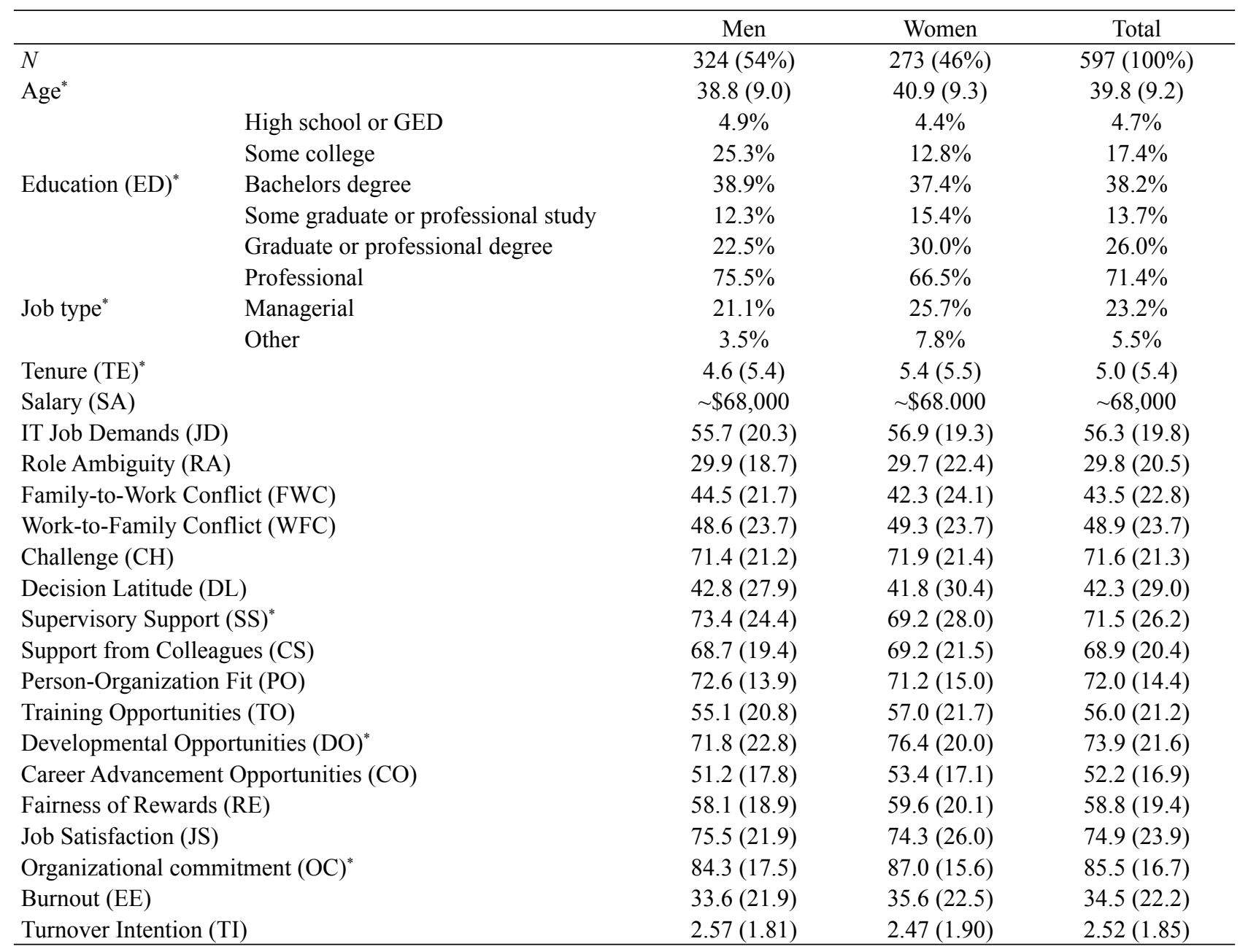

${ }^{*}$ Differences between men and women are statistically significant at $p<.05$

For testing the hypotheses we used the following statistical procedures: First, we used a group comparison test $\left(t\right.$-tests and $\left.\chi^{2}\right)$ to test the direct effect of gender on job demands and job resources, stress/burnout/job satisfaction/commitment and turnover intention (H3). Second, we used path analyses with maximum likelihood estimation to test hypotheses H1, H2 and H4 (see Figure 1). Second, we used path analyses to test hypotheses H1, H2 and $\mathrm{H} 4$ (see Figure 1). We started with a full path model (M1), including all variables and pathways, interactions between demands and job satisfaction/commitment on one hand, and between resources and stress/burnout on the other hand for men and women simultaneously. Next, we improved the path model by removing non-significant variables and paths. This model (M2) was used for testing hypotheses $\mathrm{H} 1$ and $\mathrm{H} 2$. The improved path model was tested separately for men and women in a multi-group analysis to test for a moderating effect of gender (H4). SPSS-AMOS version 17 was used for the analyses.

\section{Results}

Results of the path analysis show that the full path model (M1) shows an insufficient fit (both GFI and AGFI $<0.90$; SRMR $>0.05$; and RSMEA $>0.05$, see Table 4). We improved the full model by deleting all insignificant variables and pathways (for details of the improvement process, see Hoonakker, Carayon, Schoepke, \& Marian (2004)). In the final path model (M2), almost all relations between job demands and job resources are mediated by emotional exhaustion and job satisfaction (see Figure 2). Thus, hypothesis 2 (the relationship between job and organizational characteristics and turnover intention is mediated by quality of working life variables) can be largely confirmed with emotional exhaustion (burnout) and job satisfaction as mediating variables.

There are three exceptions, i.e., direct paths between "family life spills over into working life" and turnover intention, lack of work-related challenges and turnover 
Table 3. Summary of measures used in the study

\begin{tabular}{|c|c|c|c|c|c|c|}
\hline Scale name & Source & $\begin{array}{l}\text { Number } \\
\text { of items }\end{array}$ & $\begin{array}{l}\alpha \text { for sample } \\
\text { and (original } \\
\alpha \text { ) reported }\end{array}$ & $M(S D)$ & $\begin{array}{l}\operatorname{Min} / \\
\operatorname{Max}\end{array}$ & Example question \\
\hline IT Demands (JD) & $\begin{array}{l}\text { Adapted from } \\
\text { (Quinn et al., } \\
\text { 1971) }\end{array}$ & 7 & $\begin{array}{l}.87 \\
(.81)\end{array}$ & $\begin{array}{l}71.75 \\
(19.57)\end{array}$ & $0-100$ & $\begin{array}{l}\text { How often does your job require you to } \\
\text { work very hard? }\end{array}$ \\
\hline $\begin{array}{l}\text { Role ambiguity } \\
\text { (RA) }\end{array}$ & $\begin{array}{l}\text { (Caplan et al., } \\
\text { 1975) }\end{array}$ & 4 & $\begin{array}{l}.87 \\
(.91)\end{array}$ & $\begin{array}{l}68.30 \\
(19.30)\end{array}$ & $0-100$ & $\begin{array}{l}\text { How often are you clear on what your } \\
\text { job responsibilities are? }\end{array}$ \\
\hline $\begin{array}{l}\text { Family-to-work } \\
\text { conflict (FWC) }\end{array}$ & $\begin{array}{l}\text { (Grzywacz \& } \\
\text { Marks, 2000) }\end{array}$ & 4 & $\begin{array}{l}.70 \\
(.81)\end{array}$ & $\begin{array}{c}47.88 \\
(18.13)\end{array}$ & $0-87$ & $\begin{array}{l}\text { Family matters reduce the time I can } \\
\text { devote to my job. }\end{array}$ \\
\hline $\begin{array}{l}\text { Work-to-Family } \\
\text { Conflict (WFC) }\end{array}$ & $\begin{array}{l}\text { (Grzywacz \& } \\
\text { Marks, 2000) }\end{array}$ & 4 & $\begin{array}{l}.68 \\
(.84)\end{array}$ & $\begin{array}{l}53.67 \\
(20.62)\end{array}$ & $6-100$ & $\begin{array}{l}\text { My job reduces the amount of time I } \\
\text { can spend with my family. }\end{array}$ \\
\hline Challenge $(\mathrm{CH})$ & $\begin{array}{l}\text { (Seashore et al. } \\
\text { 1982) }\end{array}$ & 4 & $\begin{array}{l}.82 \\
(.81)\end{array}$ & $\begin{array}{c}75.23 \\
(19.55)\end{array}$ & $17-100$ & $\begin{array}{l}\text { On my job, I seldom get a chance to use } \\
\text { my special skills and abilities. }\end{array}$ \\
\hline $\begin{array}{l}\text { Decision latitude } \\
\text { (DL) }\end{array}$ & $\begin{array}{l}\text { (McLaney \& } \\
\text { Hurrell, 1988) }\end{array}$ & 4 & $\begin{array}{l}.89 \\
(.90)\end{array}$ & $\begin{array}{l}40.05 \\
(25.83)\end{array}$ & $0-100$ & $\begin{array}{l}\text { How much influence do you have over } \\
\text { the decisions as to when things will be } \\
\text { done in your work unit? }\end{array}$ \\
\hline $\begin{array}{l}\text { Supervisor support } \\
\text { (SS) }\end{array}$ & $\begin{array}{l}\text { (Caplan et al., } \\
\text { 1975) }\end{array}$ & 4 & $\begin{array}{l}.83 \\
(.90)\end{array}$ & $\begin{array}{c}63.67 \\
(25.32)\end{array}$ & $0-100$ & $\begin{array}{l}\text { How much does your immediate } \\
\text { supervisor (boss) go out of his/her way } \\
\text { to do things to make your life easier for } \\
\text { you? }\end{array}$ \\
\hline $\begin{array}{l}\text { Colleagues support } \\
\text { (CS) }\end{array}$ & $\begin{array}{l}\text { (Caplan et al., } \\
\text { 1975) }\end{array}$ & 4 & $\begin{array}{l}.79 \\
(.85)\end{array}$ & $\begin{array}{c}68.27 \\
(19.79)\end{array}$ & $0-100$ & $\begin{array}{l}\text { How easy is it to talk with other people } \\
\text { at work? }\end{array}$ \\
\hline $\begin{array}{l}\text { Person- } \\
\text { Organization Fit } \\
\text { (PO) }\end{array}$ & $\begin{array}{l}\text { Adapted from } \\
\text { (Nixon, 1985a) }\end{array}$ & 13 & $\begin{array}{l}.86 \\
(.88)\end{array}$ & $\begin{array}{c}74.54 \\
(13.10)\end{array}$ & $29-100$ & $\begin{array}{l}\text { I understand my company's principles } \\
\text { and goals and support them. }\end{array}$ \\
\hline $\begin{array}{l}\text { Training } \\
\text { opportunities (TO) }\end{array}$ & $\begin{array}{l}\text { Developed in pilot } \\
\text { study (Carayon, } \\
\text { Brunette, Schwarz, } \\
\text { Hoonakker, \& } \\
\text { Haims, 2003) }\end{array}$ & 12 & .92 & $\begin{array}{l}47.16 \\
(20.59)\end{array}$ & $0-100$ & $\begin{array}{l}\text { I am given a real opportunity to improve } \\
\text { my skills at this company through } \\
\text { education and training programs. }\end{array}$ \\
\hline $\begin{array}{l}\text { Development } \\
\text { opportunities (DO) }\end{array}$ & $\begin{array}{l}\text { Adaped from } \\
\text { (Igbaria \& } \\
\text { Wormley, 1992) }\end{array}$ & 5 & .85 & $\begin{array}{l}72.69 \\
(21.74)\end{array}$ & $0-100$ & $\begin{array}{l}\text { Management development: Programs or } \\
\text { activities designed to teach managerial } \\
\text { skills, such as supervision, coaching, } \\
\text { recruiting, management decision } \\
\text { making, strategic policy making. }\end{array}$ \\
\hline $\begin{array}{l}\text { Career } \\
\text { advancement } \\
\text { opportunities }(\mathrm{CO})\end{array}$ & $\begin{array}{l}\text { Adapted from } \\
\text { (Nixon, 1985b) }\end{array}$ & 10 & $\begin{array}{l}.81 \\
(.89)\end{array}$ & $\begin{array}{c}47.89 \\
(15.86)\end{array}$ & $10-80$ & $\begin{array}{l}\text { My opportunities for advancement in } \\
\text { this company are somewhat limited. }\end{array}$ \\
\hline $\begin{array}{l}\text { Fairness of rewards } \\
\text { (RE) }\end{array}$ & $\begin{array}{l}\text { Adapted from } \\
\text { (Vandenberg et al., } \\
\text { 1999) }\end{array}$ & 8 & $\begin{array}{l}.84 \\
(.86)\end{array}$ & $\begin{array}{c}50.84 \\
(17.95)\end{array}$ & $4-100$ & $\begin{array}{l}\text { My performance evaluations within the } \\
\text { past few years have been helpful to me } \\
\text { in my professional development. }\end{array}$ \\
\hline $\begin{array}{l}\text { Job satisfaction } \\
\text { (JS) }\end{array}$ & $\begin{array}{l}\text { (Quinn et al., } \\
\text { 1971) }\end{array}$ & 5 & $\begin{array}{l}.78 \\
(.80)\end{array}$ & $\begin{array}{l}72.44 \\
(22.60)\end{array}$ & $10-100$ & $\begin{array}{l}\text { Knowing what you know now, if you } \\
\text { had to decide all over again whether to } \\
\text { take the job you now have, what would } \\
\text { you decide? }\end{array}$ \\
\hline $\begin{array}{l}\text { Organizational } \\
\text { commitment (OC) }\end{array}$ & $\begin{array}{l}\text { (Cook \& Wall, } \\
1980)\end{array}$ & 3 & $\begin{array}{l}.72 \\
(.68)\end{array}$ & $\begin{array}{c}80.24 \\
(15.43)\end{array}$ & $17-100$ & $\begin{array}{l}\text { In my work, I like to feel I am making } \\
\text { some effort, not just for myself but for } \\
\text { the organization as well. }\end{array}$ \\
\hline $\begin{array}{l}\text { Emotional } \\
\text { exhaustion (EE) }\end{array}$ & $\begin{array}{l}\text { (Maslach \& } \\
\text { Jackson, 1986) and } \\
\text { (Geurts, Schaufeli, } \\
\text { \& De Jonge, 1998) }\end{array}$ & 6 & .87 & $\begin{array}{c}41.04 \\
(22.51)\end{array}$ & $0-100$ & I feel emotional drained from my work. \\
\hline $\begin{array}{l}\text { Intention to } \\
\text { turnover (TI) }\end{array}$ & $\begin{array}{l}\text { Michigan } \\
\text { Organizational } \\
\text { Assessment } \\
\text { Scale (MOAQ) } \\
\text { and (Seashore, } \\
\text { Lawler, Mirvis, \& } \\
\text { Cammann, 1982) }\end{array}$ & 1 & $\mathrm{n} / \mathrm{a}$ & $\begin{array}{c}2.87 \\
(1.83)\end{array}$ & $1-7$ & $\begin{array}{l}\text { How likely is it that you will actively } \\
\text { look for a new job in the next year? }\end{array}$ \\
\hline
\end{tabular}


Table 4. Path models: goodness of fit statistics

\begin{tabular}{lrrrrrrrrr}
\hline & \multicolumn{1}{c}{$\chi^{2}$} & \multicolumn{1}{c}{$d f$} & \multicolumn{1}{c}{$p$} & GFI & AGFI & NFI & CFI & SRMR & RMSEA \\
\hline Null Model (M0) & 3416.8 & 153 & $<.001$ & .45 & .39 & .00 & .00 & .000 & .190 \\
Full model (M1) & 1034.4 & 89 & $<.001$ & .85 & .71 & .71 & .71 & .170 & .130 \\
Final model (M2), full sample & 62.9 & 35 & .003 & .99 & .96 & .98 & .99 & .030 & .036 \\
Final model for men & 36.0 & 35 & .420 & .99 & .95 & .98 & 1.00 & .029 & .001 \\
Final model for women & 55.1 & 35 & .020 & .97 & .92 & .97 & .99 & .044 & .046 \\
\hline
\end{tabular}

Note. GFI = goodness of fit index; AGFI = adjusted goodness of fit index; NFI = normative goodness of fit index; CFI = comparative goodness of fit index; SRMR = standardized root mean square residual; RMSEA = root mean square error of approximation.

intention, and fairness of rewards and turnover intention. Only one out of 24 possible moderation paths between job demands and job satisfaction on one hand and job resources and stress on the other hand is significant (career opportunities and exhaustion). Thus, hypothesis 1 (there are two pathways to turnover intention) can also be largely confirmed. The core assumptions of the job demands-resources model are confirmed in this sample of IT workers.

Table 2 shows the results of a comparison between men and women for variables in the model. Women in the sample are significantly older; they have a significantly higher level of education; they are more likely to hold a managerial job type; they have more years of tenure in the organization and earn about the same salary as men do; they receive less supervisory support; have more developmental opportunities and are more committed to their organization. Except in the case of supervisory

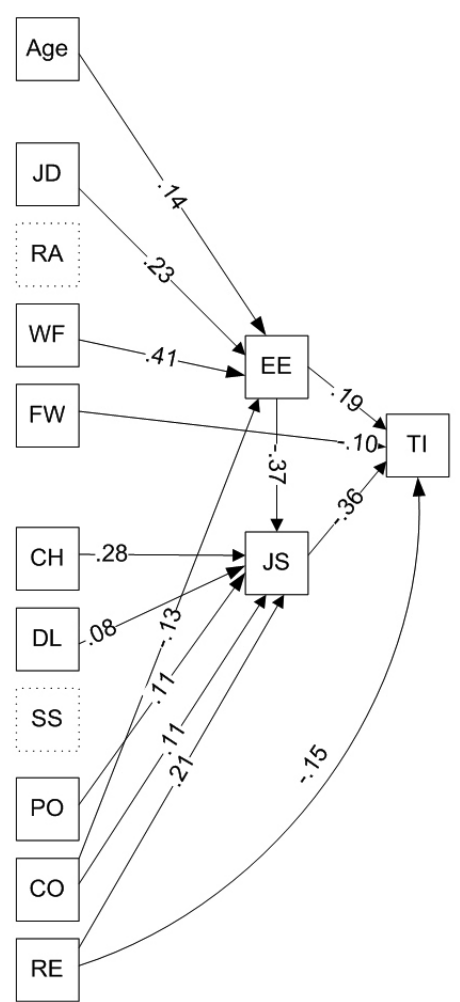

$\mathrm{JD}=$ Job Demands RA= Role Ambiguity $\mathrm{WF}=$ Work spills over into Family life $\mathrm{FW}=$ Family life spills over into Work

$\mathrm{CH}=$ Challenge

$\mathrm{DL}=$ Decision Latitude SS= Supervisory Support $\mathrm{PO}=$ Person Organization fit $\mathrm{CO}=$ Career Opportunities $\mathrm{RE}=$ Fairness of Rewards

$\mathrm{EE}=$ Emotiona Exhaustion JS=Job Satisfaction

TI=Turnover Intention

Figure 2. Job demands-resources - turnover intention path model. support, H3 (gender has a direct effect on the variables in the model) can be rejected.

To test hypothesis 4 (gender moderates the relation between job and organizational factors and HRM practices and QWL, and also moderates the relationship between QWL and turnover intention) we conducted a multi-group analysis, using the final model (M2).

As the goodness of fit statistics in Table 2 show, the model fits the data for men better than for women. Results of the multi-groups analysis show that that both the structural weights (Beta-coefficients) and covariances (correlations between job and organizational characteristics and HRM practices) differ statistically significant for men and women $\left(\chi^{2}=32.7, d f=20, \mathrm{p}=0.04\right.$ and $\chi^{2}=100.9, d f=66, p=0.03$ respectively). Therefore, hypothesis 4 is confirmed.

Figure 3 shows the final models for men and women separately. Results of path analysis confirm the central role of emotional exhaustion and (lack of) job satisfaction. Results also show that over half of the relationships between job and organizational characteristics and turnover intention in the model for men are mediated by emotional exhaustion. In the model for women over half of the relations are mediated by (lack of) job satisfaction. In the model for men there are direct relationships between family-to-work conflict and fairness of rewards and turnover intention. In the model for women there are direct relations between "(lack of) work-related challenges" and "fairness of rewards" and turnover intention. In the male model, supervisory support and decision latitude do not play a significant role. In the female model, family life spills over into work and person-organization fit do not play a significant role.

\section{Discussion}

Turnover has been a problem for IT organizations since the 1960s. Since then, several studies have been conducted to shed light on the problem. One particular point of interest is the difference in turnover and turnover intention between men and women. In our study, we adapted the Job-Demands-Resources (JD-R) Model to examine the general relationships between job demands, emotional exhaustion and turnover intention on the one hand and the relationship between job resources, job satisfaction, 
MEN

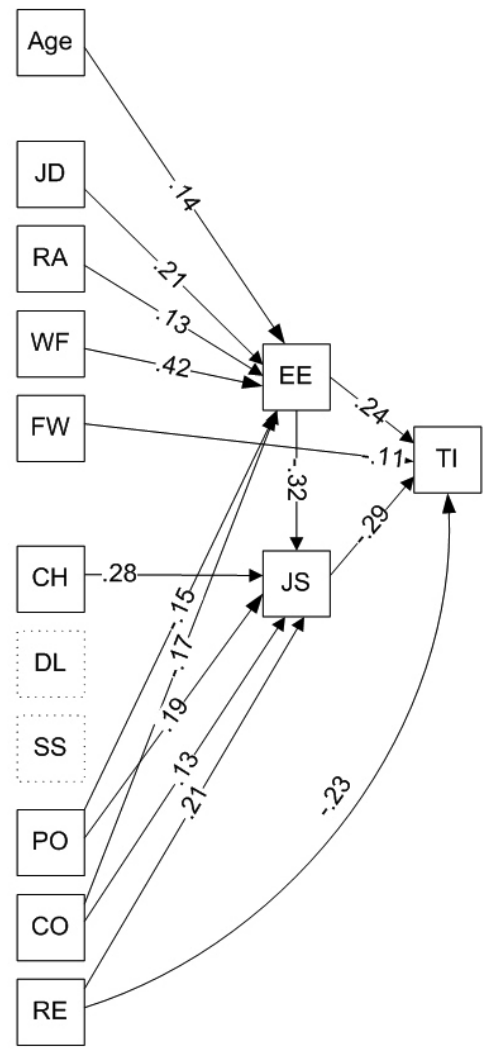

WOMEN

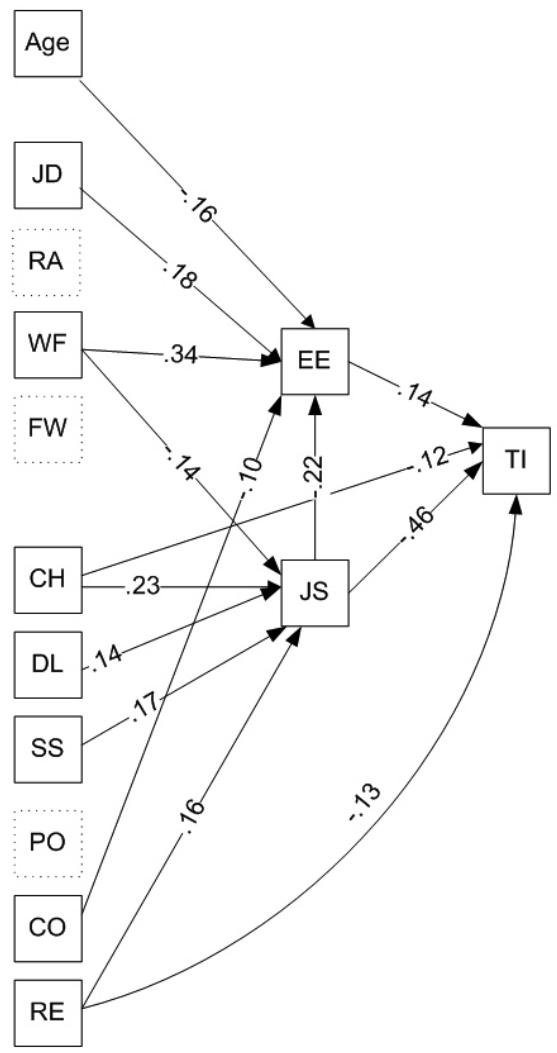

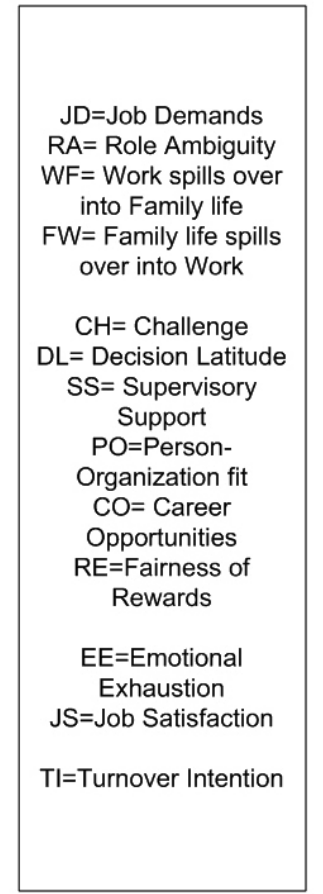

Figure 3. Job demands-resources - turnover intention path model (men/women).

organizational commitment and turnover intention on the other hand. We tested the basic assumptions of the model in a sample of Information Technology (IT) workers, and also separately for men and women. In general, our results support the assumptions of the JD-R model. Results show that there indeed seem to be two, more or less independent pathways to turnover intention. The first (energetic) pathway follows the relationships between job demands, job stress, and turnover intention. The second pathway follows the relationship between job resources, job satisfaction and turnover intention. Results of our study also show support for the hypothesis that the relationship between job demands and turnover intention is mediated by strain, and that the relationship between job resources and turnover intention is mediated by job satisfaction.

Not all variables fit the adapted JD-R model perfectly. First, although most of the relationships were in the expected directions (job demands $\rightarrow$ strain $\rightarrow$ turnover intention; and job resources $\rightarrow$ job satisfaction and organizational commitment $\rightarrow$ turnover intention), there is an exception: the variable person-organization fit is related to both job satisfaction and emotional exhaustion. Second, not all relationships between job demands and turnover intention are fully mediated by emotional exhaustion, and not all relationships between job resources and turnover intention are fully mediated by job satisfaction. The energetic pathway is not fully mediated by emotional exhaustion: there is a direct effect from family life spills over into work (especially for men). The motivational pathway is not fully mediated by job satisfaction: there is a direct effect of fairness of rewards on turnover intention, as well as an indirect effect through job satisfaction. Last, organizational commitment, one of the variables that previous research has shown to be strongly related to turnover intention does not play a significant role in our model. An explanation could be that tenure in the IT workforce is too short for employees to become really committed to the organization they work for. Tenure of IT personnel is on an average two years.

In general, the energetic pathway (job demands $\rightarrow$ strain $\rightarrow$ turnover intention) seems to play a stronger role in the model for men than for women. The motivational pathway (job resources $\rightarrow$ job satisfaction $\rightarrow$ turnover intention) seems to play a stronger role in the model for women than for men (see Figure 3). The difference between the model for men and the model for women is statistically significant. We tested whether gender has a direct effect on job demands and job resources, strain, job satisfaction and turnover intention, or whether gender moderates these relationships. We found very few gender differences in job demands and job resources, strain, job satisfaction and turnover intention (see Table 3). The gender differences 
that are statistically significant show that women in our sample are relatively higher educated, report more developmental opportunities and a higher organizational commitment but also that they receive less supervisory support. We did find that the relationships between job demands and job resources, strain, job satisfaction and turnover intention are statistically different for men and women.

In contrast to these results, several earlier studies on turnover in the IT workforce, especially the studies conducted by Igbaria and colleagues (Igbaria \& Baroudi, 1995; Igbaria \& Chidambaram, 1995; 1997; Igbaria, Parasuraman, \& Greenhaus, 1997) in the 1990s, did show significant gender differences in job demands and job resources, strain, job satisfaction and turnover intention. Igbaria and colleagues explained these gender differences from a human-capital perspective. According to the human-capital paradigm continued gender (and racial) discrimination can be explained because individuals are rewarded in their jobs for their investment in education and job training (Blau \& Ferber, 1987). The paradigm suggests that women accumulate less human capital (knowledge and skills derived from on-the-job training and continuous work experience) than men do, because women have lower educational levels, less experience and fewer skills, particularly in professional and managerial areas (Igbaria \& Chidambaram, 1997). In several of their studies, Igbaria and colleagues found support for the human-capital paradigm: women in their studies were less experienced, lower educated, earned less, and less often held managerial positions (Igbaria et al., 1997; Igbaria \& Chidambaram, 1997). Historically, women have had lower levels of educational attainment (Freeman, 2004; National Center for Education Statistics, 1999), which in turn could negatively affect their opportunities in the labor market. However, in the past decade, this has changed dramatically. In general, more women have completed college, and more women have received Bachelor's and Master's degrees than men. Only in the highest level of education (Ph.D.), men hold more degrees than women (National Center for Education Statistics, 1999, 2002). Although women have made tremendous progress in social sciences, history, psychology, biological sciences/life sciences, business management and administrative services where they have attained relative gender parity or made up the majority in 2001, other fields such as computer and information sciences, physical sciences, science technologies, and engineering continue to have a larger proportion of males. However, the percentage of females majoring in those fields is increasing (Freeman, 2004).

Why do the relationships, based on the JD-R model, vary across gender? The most striking difference in the relationship is that for women, job satisfaction plays a crucial role. In their study on gender differences in turnover intention, Miller and Wheeler (1992) found that turnover intention among women was twice as high as men in comparable occupations. However, after controlling for age and job dissatisfaction, the gender effect disappeared.
The researchers also found that meaningfulness of work was a strong predictor of intention to leave for women. We found similar results in a study on gender differences in job and organizational factors as predictors of quality of working life (Hoonakker, Marian, \& Carayon, 2004). For female employees in the IT department of a large public organization, task identity was one of the most important factors explaining gender differences in quality of working life (job strain, job commitment and job satisfaction). Task identity is the extent to which employees do an entire piece of work (instead of small parts) and can clearly identify the results of their effort (Sims, Szilgyi, \& Keller, 1976). Campbell and Perlman (2006) found similar results. They found that the only gender differences in job satisfaction was that women more often than men found failure to see much meaning in their work a more frequent source of job dissatisfaction. This can also explain why lack of workrelated challenges has a direct effect on turnover intention for women and not for men.

The study limitations include the fact that data were collected from only five companies, therefore limiting the generalizability of the results. Also, these data are crosssectional which limits the interpretation regarding causal relationships between job demand and resources, strain and attitudinal factors, and turnover intention. Finally, this research is focused on turnover intention, not actual turnover.

The results of our study have implications for retention of personnel in the IT workforce. To reduce turnover intention, and associated turnover of personnel, organizations have two possibilities: (1) ensure that job demands are not too high, in that way prevent burnout and consequently turnover intention (especially for men), and (2) ensure that personnel have enough resources, and remain satisfied with their job, thereby reducing turnover intention (especially for women).

Further, for both men and women, there is a direct relation between fairness of rewards and turnover intention. Therefore, in order to retain their IT personnel, companies should create a system that guarantees the fairness of the reward system. Attention should be paid for example to the relationship between how well employees perform and the likelihood of receiving recognition and praise, receiving a raise in pay and receiving high performance appraisal ratings.

Finally, our results show that work-family conflict also plays an important role. For both men and women in the study, 'work-to-family conflict is strongly related to burnout. Burnout in turn is strongly related to turnover intention. Therefore, IT companies should examine the possibility of offering family-friendly practices to help employees better balance work and family. Results of analysis on effective Human Resource Management practices to retain personnel have shown that offering family-friendly practices, such as telecommuting and part time work to retain IT personnel, can be effective (Hoonakker, Carayon, Marian, \& Schoepke, 2004). IT personnel who can make use of these options, who think 
the options are sufficient for their needs and who do not feel discouraged from taking advantage of these options are significantly more willing to stay with their company. Research has shown that employees who can take advantage of these practices are more than three times more likely to remain with their company (Hoonakker et al., 2004).

Acknowledgements. Funding for this research was provided by the National Science Foundation (NSF) Information Technology Workforce Program (Project \#EIA-0120092). We would like to thank all of the participating companies and their employees for agreeing to be involved in our research project. We would like to thank Randi Cartmill for reviewing and editing earlier versions of this manuscript.

\section{References}

Agarwal, R., \& Ferratt T. W. (2002). Toward understanding the relationship between IT human resource management systems and retention: An empirical analysis based on multiple theoretical and measurement approaches. In M. Adya, R. Horton, H. Huang, \& J. L. Quesenberry (Eds.), SIGCPR'02 Proceedings of the 2002 ACM SIGCPR conference on Computer personnel research (pp.126-138). New York, NY, USA: $A C M$.

Ahuja, M. K. (2002). Women in the information technology profession: A literature review, synthesis and research agenda. European Journal of Information Systems, $11,20-34$.

Armstrong, D. J., Riemenschneider, C. K., Allen, M. W., \& Reid, M. (2007) Advancement, voluntary turnover and women in IT: A cognitive study of workfamily conflict. Information \& Management, 10(2), 142-153.

Arnold, H. F., \& Feldman, D. C. (1982). A multivariate analysis of the determinants of job turnover. Journal of Applied Psychology, 67, 350-360.

Bakker, A. B. (2007). The Job Demands-Resources Model. Journal of Managerial Psychology, 22, 309-328.

Bakker, A. B., Demerouti, E., \& Schaufeli, W. B. (2003). Dual processes at work in a call centre: An application of the Job Demands - Resources model. European Journal of Work and Organizational Psychology, 12(4), 393-417.

Bakker, A. B., Demerouti, E., \& Verbeke, W. (2004). Using the Job-Demand-Resources Model to predict burnout and performance. Human Resource Management, 43, 83-104.

Bannister, B. D., \& Griffeth, R. W. (1986). Applying a causal analytic framework to the Mobley, Horner and Hollingsworth (1978) turnover model: A useful reexamination. Journal of Management, 12, 433-443.
Baroudi, J. J. (1985). The impact of role variables on IS personnel work attitudes and intentions. MIS Quarterly, 9, 341-356.

Baroudi, J. J., \& Igbaria, M. (1995). An examination of gender effects on career success of information systems employees. Journal of Management Information Systems, 11, 181-210.

Barrios, E. (2003). Web Survey Mailer System (WSMS 1.1): CQPI Report Series. Madison, WI, USA: Center for Quality and Productivity Improvement.

Becker-Blease, J., Elkinawy, S., \& Stater, M. (2010). The impact of gender on voluntary and involuntary executive departure. Economic Inquiry, 48(4), 1102-1118.

Beehr, T. A., Glaser, K. M., Canali, K. G., \& Wallwey, D. A. (2001). Back to basics: Re-examination of Demand-Control Theory of occupational stress. Work \& Stress, 15, 115-130.

Blau, F. D., \& Ferber, M. A. (1987). Occupations and earning of women workers. In K. S. Koziara, M. H. Moskow, \& L. D. Tanner (Eds.), Working Women: Past, Present, Future (pp. 37-68). Washington, DC, USA: BNA Books.

Blau, G., \& Boal, K. B. (1987). Conceptualizing how job involvement and organizational commitment affect turnover and absenteeism. Academy of Management Review, 12, 288-300.

Bluedorn, A. C. (1982). A unified model of turnover from organizations. Human Relations, 35, 135-153.

Borman, W. C. (1991). Job behavior, performance, and effectiveness. In M. D. Dunnette, \& L. M. Hough (Eds.), Handbook of industrial and organizational psychology ( pp. 271-326). Palo Alto, CA, USA: Consulting Psychologists Press.

Burke, R. J., \& Greenglass, E. (1995). A longitudinal study of psychological burnout in teachers. Human Relations, 48, 187-202.

Campbell, P. B., \& Perlman, L. K. (2006). What brings workers to the Information technology and why do they stay? In National Science Foundation's ITWF\&ITR/EWF Principal Investigator Conference (pp. 81-88). Raleigh, NC, USA.

Caplan, R. D., Cobb, S., French, J. R. P., Harrison, R. V., \& Pinneau, S. R. (1975). Job demands and worker health. Washington, DC, USA: US Government Printing Office.

Carayon, P., Schoepke, J., Hoonakker, P. L. T., Haims, M. C., \& Brunette, M. (2006). Evaluating the causes and consequences of turnover intention among IT users: The development of a questionnaire survey. Behaviour and Information Technology, 25, 381-397.

CAWMSET (2000). Land of plenty: Diversity as America's competitive edge in science, engineering and technology. Washington, DC, USA: Congressional Commission on the Advancement of Women and Minorities in Science, Engineering and Technology Development. 
Compton, T. R. (1987). Job satisfaction among systems personnel. Journal of System Management, 38, 28-31.

Cook, J., \& Wall, T. D. (1980). New work attitudes measures of trust, organizational commitment, and personal need non-fulfilment. Journal of Occupational Psychology, 53, 39-52.

Cotton, J. L., \& Tuttle, J. M. (1986). Employee turnover: A meta-analysis and review with implications for research. Academy of Management Review, 11, $55-70$.

Dubie, D. (2009, November 18). CIOs fear mass IT exodus following economic recovery. Networkworld. Retrieved from http://www.networkworld.com

Firth, H., \& Britton, P. (1989). Burnout: Absence and turnover amongst British nursing staff. Journal of Occupational Psychology, 62, 55-60.

Fishbein, M., \& Ajzen, I. (1975). Belief, attitude, intention and behavior: An introduction to theory and research. Reading, MA, USA: Addison-Wesley.

Freeman, C. E. (2004). Trends in educational equity of girls \& women: 2004. Washington, DC, USA: U.S. Government Printing Office, U.S. Department of Education, National Center for Education Statistics.

Frone, M. R., Russell, M., \& Copper, M. L. (1992). Antecedents and outcomes of work-family conflict: Testing a model of the work-family interface. Journal of Applied Psychology, 77, 65-78.

Frone, M. R., Yardley, J. K., \& Markel, K. S. (1997). Developing and testing an integrative model of the work-family interface. Journal of Vocational Behavior, 50, 145-167.

Gerhart, B., \& Milkovich, G. T. (1992). Employee compensation: Research and practice. In M. D. Dunnette \& L. M. Hough (Eds.), Handbook of industrial and organizational psychology (pp. 481569). Palo Alto, CA, USA: Consulting Psychologists Press.

Googins, B.K. (1991). Work/family conflicts: Private lives, public responses. New York, NY, USA: Aburn House.

Grant-Vallone, E. J., \& Donaldson, S. I. (2001). Consequences of work-family conflict on employee well-being over time. Work \& Stress, 15, 214-226.

Greenhaus, J. H., \& Beutell, N. J. (1985). Sources of conflict between work and family roles. Acadamy of Management Review, 10(1), 76-88.

Griffeth, R., Hom, P., \& Gaertner, S. (2000). A metaanalysis of antecedents and correlates of employee turnover: Update, moderator tests, and research implications for the next millennium. Journal of Management, 26, 463-488.

Grzywacz, J. G., \& Marks, N. F. (2000). Reconceptualizing the work-family interface: An ecological perspective on the correlates of positive and negative spillover between work and family. Journal of Occupational Health Psychology, 5, 111-126.
Guzzo, R. A., Jette, R. D., \& Katzell, R. A. (1985). The effect of psychologically based intervention programs in worker productivity: A meta-analysis. Personnel Psychology, 38, 275-291.

Hayes, F. (1998). Don't underestimate the labor shortage; it's real, despite the hoopla surrounding it. Computerworld Marion, 32(5), 8-11.

Higgins, C. A., \& Duxbury, L. E. (1992). Work-family conflict: A comparison of dual-career and traditional career men. Journal of Organizational Behavior, 13, 389-411.

Hom, P. W., Caranikas-Walker, F., Prussia, G. E., \& Griffeth, R. W. (1992). A meta-analytical structural equations analysis of a model of employee turnover. Journal of Applied Psychology, 77, 890-909.

Hoon, S. C. \& Jing, Q. (2011). A global perspective on information systems personnel turnover. Journal of Global Information Technology Management, 14(4), 4-27.

Hoonakker, P. L. T., Carayon, P., Marian, A., \& Schoepke, J. (2004). Shortage of skilled workers and high turnover in the information technology workforce: What are the possibilities for retention? In H. M. Khalid, M. G. Helander, \& A. W. Yeo (Eds.), $W W C S$ 2004 Conference (pp. 132-137). Kuala Lumpur, Malaysia: Damai Sciences.

Hoonakker, P. L. T., Carayon, P., \& Schoepke, J. (2005). Work family conflict in the IT work force. In P. Carayon, B. Kleiner, M. Robertson, \& P. Hoonakker (Eds.), Human Factors in Organizational Design and Management - VIII Conference (pp. 81-86). Maui, Hawaii: IEA Press.

Hoonakker, P. L. T., Carayon, P., Schoepke, J., \& Marian, A. (2004). Job and organizational factors as predictors of turnover in the IT workforce: Differences between men and women. In WWCS 2004 Conference (pp. 126-131). Kuala Lumpur, Malaysia: Damai Sciences.

Hoonakker, P. L. T., Marian, A., \& Carayon, P. (2004, September). The relation between job characteristics and quality of working life: The role of task identity to explain gender differences. In Proceedings of the Human Factors and Ergonomics Society 48th Annual Meeting Annual Meeting, New Orleans, Louisiana,USA , 48(14), 1571-1575.

Houkes, I., Janssen, P., De Jonge, J., \& Bakker, A. B. (2003). Specific determinants of intrinsic work motivation, emotional exhaustion and turnover intention: A multisample longitudinal study. Journal of Occupational Psychology, 76, 427-450.

Huselid, M. A. (1995). The impact of human resource management practices on turnover, productivity, and corporate financial performance. Academy of Management Journal, 38, 635-672.

Igbaria, M., \& Baroudi, J. J. (1995). The impact of job performance evaluations on career advancement prospects: An examination of gender differences in the IT work force. MIS Quarterly, 19, 107-123. 
Igbaria, M., \& Chidambaram, L. (1995). Examination of gender effects on intention to stay among information systems employees. In L. Olfman (Ed.), Proceedings of the 1995 ACM SIGCPR Conference, Nashville, Tennessee, USA (pp. 167-80). New York, NY: ACM.

Igbaria, M., \& Chidambaram, L. (1997). The impact of gender on career success of information systems professionals: A human capital perspective. Information Technology \& People, 10, 63.

Igbaria, M., \& Greenhaus, J. (1992). Determinants of MIS employees' turnover intentions: A structural equation model. Communications of the ACM, 35, 35-49.

Igbaria, M., \& Guimaraes, T. (1999). Exploring differences in employee turnover intentions and its determinants among telecommuters and non-telecommuters. Journal of Management Information Systems, 16, 147-164.

Igbaria, M., Parasuraman, S., and Greenhaus, J. H. (1997). Status report on women and men in the IT workplace. Information Systems Management, 14, 44-53.

Igbaria, M., \& Siegel, S. R. (1992). The reasons for turnover of information systems personnel. Information and Management, 23, 321-330.

Igbaria, M., \& Wormley, W. M. (1992). Organizational experiences and career success of MIS professionals and managers: An examination of race differences. MIS Quarterly, 16(4), 507-529.

Jackson, S. E., Turner, J. A., \& Brief, A. P. (1986). Correlates of burnout among public service lawyers. Journal of Occupational Behavior, 8, 339-349.

Janssen, P., De Jonge, J., \& Bakker, A. B. (1999). Specific determinants of intrinsic work motivation, burnout and turnover intentions: a study among nurses. Journal of Advanced Nursing, 29, 1360-1369.

Jawahar, I. M., \& Hemmasi, P. (2006). Perceived organizational support for women's advancement and turnover intentions: The mediating role of job and employer satisfaction. Women in Management Review, 21, 643-661.

Jiang, J. J., \& Klein, G. (2002). A discrepancy model of Information System personnel turnover. Journal of Management Information Systems, 19, 249-272.

Kalimo, R., \& Toppinen, S. (1995). Burnout in computer professionals. In Proceedings of the Work, Stress and Health 1995: Creating Healthier Workplaces. Washington, DC, USA.

Kim, H., \& Stoner, M. (2008). Burnout and turnover intention among social workers: Effects of role stress, job autonomy and social support. Administration in Social Work, 32, 5-25.

Lawler, E. E. (1986). High involvement management. San Francisco, CA: Jossey-Bass.

Lawler, E. E. (1992). The ultimate advantage: Creating the high involvement organization. San Francisco, CA, USA: Jossey-Bass.

Lawler, E. E. (1996). From the ground up: Six principles for building the new logic corporation. San Francisco, CA, USA: Jossey-Bass.
Lee, P. C. B. (2004). Social support and leaving intention among computer professionals. Information \& Management, 41, 323-334.

Leiter, M. P. (1991). Coping patterns as predictors of burnout: The function of control and escapist coping. Journal of Occupational Behavior, 12, 123-144.

Lewig, K. A., Xanthopoulou, D., Bakker, A. B., Dollard, M. F., \& Metzer, J. C. (2007). Burnout and connectedness among Australian volunteers: A test of the Job Demands-Resources model. Journal of Vocational Behavior, 71, 429-445.

Lyness, K. S., \& Judiesch, M. K. (2001). Are female managers quitters? The relationships of gender, promotions, and family leaves of absence to voluntary turnover. Journal of Applied Psychology, 86(6), 1167-1178.

Maslach, C., \& Jackson, S. E. (1984). Patterns of burnout among a national sample of public contact workers. Journal of Health and Human Resources Administration, 7, 189-212.

Maslach, C., \& Jackson, S. (1986). Maslach Burnout Inventory Manual. Palo Alto, CA, USA: Consulting Psychologists Press.

Mathieu, J. E., \& Zajac, D. M. (1990). A review and meta-analysis of the antecedents, correlates, and consequences of organizational commitment. Psychological Bulletin, 108, 171-194.

Mauno, S., Kinnunen, U., \& Ruokolainen, M. (2006). Exploring work- and organization-based resources as moderators between work-family conflict, wellbeing, and job attitudes. Work \& Stress, 20, 210-233.

McEvoy, G. M., \& Cascio, W. F. (1985). Strategies for reducing employee turnover: A meta-analysis. Journal of Applied Psychology, 70, 342-353.

McLaney, M. A., \& Hurrell, J. J. J. (1988). Control, stress, and job satisfaction in Canadian nurses. Work \& Stress, 2, 217-224.

McLaughlin, R. A. (1979). The old bugaboo, turnover. Damation, 25, 97-101.

Miller, G. J., \& Wheeler, K. G. (1992). Unraveling the mysteries of gender differences in intentions to leave the organization. Journal of Organizational Behavior, 13, 465-479.

Mobley, W. H. (1977). Intermediate linkages in the relationship between job satisfaction and employee turnover. Journal of Applied Psychology, 62, 237-240.

Mobley, W. H., Griffeth, R. W., Hand, H. H., \& Meglino, B. (1979). Review and conceptual analysis of the employee turnover process. Psychological Bulletin, 86, 493-522.

Mobley, W. H., Horner, S., \& Hollingsworth, A. (1978). An evaluation of precursors of hospital employee turnover. Journal of Applied Psychology, 63, 408-414.

Moore, J. E. (2000). One road to turnover: An examination of work exhaustion in technology professionals. MIS Quarterly, 24, 141-168. 
Moore, J. E., \& Burke, L. (2002). How to turn around 'turnover culture' in IT. Communications of the ACM, $45,73-78$.

Mottaz, C. J. (1988). Determinants of organizational commitment. Human Relations, 41(6), 467-482.

National Center for Education Statistics (1999). Digest of Education Statistics, 1999. Retrieved from https:// nces.ed.gov/pubsearch/pubsinfo.asp?pubid=2000031

National Center for Education Statistics (2002). Digest of Education Statistics, 2002. Retrieved from http:// nces.ed.gov/pubsearch/pubsinfo.asp?pubid $=2003060$

National Center for Woman \& Information Technology (2009). Women in IT: The facts. Retrieved from www. ncwit.org/thefacts

Nelson, A. C. (1996). Employee-job fit in MIS: Research in progress. In The ACM SIGCPR/SIGMIS Conference on Computer Personnel Research (pp. 395-399). Denver, CO, USA: ACM Press.

Niedermann, F., \& Sumner, M. (2003). Decision paths affecting turnover among information technology professionals. In M. Mandviwalla, E. M. Trauth (Eds.), Proceedings of the 2003 SIGMIS Conference on Computer Personnel Research: Freedom in Philadelphia - Leveraging Differences and Diversity in the IT Workforce (pp. 133-142).

Nixon, R. (1985a). Black managers in corporate america: Alienation or integration? Washington, DC, USA: National Urban League.

Nixon, R. (1985b). Climbing the corporate ladder: Some perceptions among black managers. Washington, DC, USA: National Urban League.

Parasuraman, S. (1982). Predicting turnover intentions and turnover behavior: A multivariate analysis. Journal of Vocational Behavior, 21, 111-121.

Pines, A., Aronson, E., \& Kafry, D. (1981). Burnout: from tedium to personal growth. New York, NY, USA: The Free Press.

Quinn, R., Seashore, S., Kahn, R., Mangion, T., Cambell, D., Staines, G., \& McCullough, M. (1971). Survey of working conditions: Final report on univariate and bivariate tables (Document No. 2916-0001). Washington, DC,USA: Government Printing Office.

Reichheld, F. F. (1996). The loyalty effect. Boston, MA: The Harvard Business School Press.

Rhoades, L., \& Eisenberger, R. (2002). Perceived organizational support: A review of the literature. Journal of Applied Psychology, 87, 698-714.

Seashore, S. E., Lawler, E. E., Mirvis, P., \& Cammann, C. (1982). Observing and measuring organizational change: A guide to field practice. New York, NY, USA: John Wiley \& Sons.

Sethi, V., Barrier, T., \& King, R. C. (1999). An examination of the correlates of burnout in Information System Professionals. Information Resources Management Journal, 12, 5-13.

Sims, H. P., Szilgyi, A. D., \& Keller, R. T. (1976). The measurement of job characteristics. Academy of Management Journal, 19, 195-212.
Sjoberg, A., \& Sverke, M. (2000). The interactive effect of job involvement and organizational commitment on job turnover revisited: A note on mediating role of turnover intention. Scandinavian Journal of Psychology, 41, 247-252.

Sonnentag, S., Brodbeck, F. C., Heinbokel, T., \& Stolte, W. (2001). Stressor-burnout relationship in software development teams. Journal of Occupational and Organizational Psychology, 67, 327-341.

Stone, M. (1972). Where go the computer people - up, down or out? Damation, 18, 68-72.

Thatcher, J. B., Stepina, L. P., \& Boyle, R. J. (2003). Turnover of information technology workers: Examining empirically the influence of attitudes, job characteristics, and external Markets. Journal of Management Information Systems, 19, 231-261.

Trauth, E. M., Quesenberry, J. L., and Huang, H. (2006). Cross-cultural influences on women in the IT Workforce. In C. Shayo, K. M. Kaiser, \& T. Ryan (Eds.), Proceedings of the 2006 ACM SIGMIS CPR Conference on Computer Personnel Research, ACM (pp. 12-19). New York, NY: ACM.

Truman, G. E., \& Baroudi, J. J. (1994). Gender differences in the information systems managerial ranks: An assessment of potential discriminatory practices. MIS Quarterly, 18(2), 129-142.

U.S. Department of Labor (1993). High performance work practices and firm performance. Washington, DC, USA: Government Printing Office.

Vanderberg, R. J., Richardson, H. A., \& Eastman, L. J. (1999). The impact of high involvement work processes on organizational effectiveness: A second-order latent variable approach. Group and Organizational Management, 24, 300-339.

Verquer, M. L., Beehr, T. A., \& Wagner, S. H. (2003). A meta-analysis of relations between personorganization fit and work attitudes. Journal of Vocational Behavior, 63, 473-489. 